\title{
Data report: frictional healing and compressibility of sheared sediment from fault zones, Sites $\mathrm{C0004}$ and $\mathrm{C0007}^{1}$
}

\author{
Matt J. Ikari, ${ }^{2,}{ }^{3}$ Matthew W. Knuth, ${ }^{4}$ Chris Marone, ${ }^{2}$ and Demian M. Saffer ${ }^{2}$
}

\section{Chapter contents}

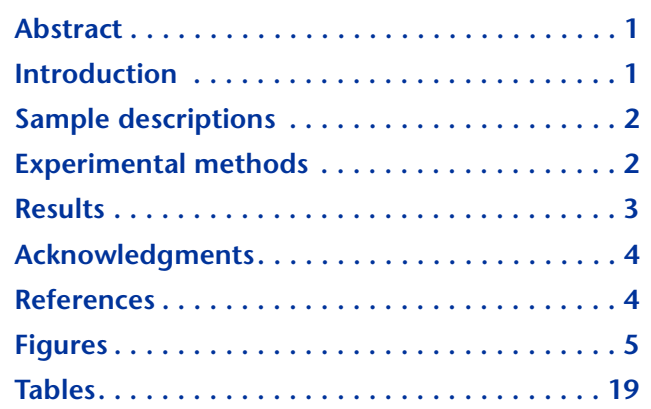

${ }^{1}$ Ikari, M.J., Knuth, M.W., Marone, C., and Saffer, D.M., 2012. Data report: frictional healing and compressibility of sheared sediment from fault zones, Sites C0004 and C0007. In Kinoshita, M., Tobin, H., Ashi, J., Kimura, G., Lallemant, S., Screaton, E.J., Curewitz, D., Masago, H., Moe, K.T., and the Expedition 314/315/316 Scientists, Proc. IODP, 314/315/316: Washington, DC (Integrated Ocean Drilling Program Management International, Inc.). doi:10.2204/iodp.proc.314315316.219.2012 ${ }^{2}$ Department of Geosciences, The Pennsylvania State University, University Park PA 16802, USA. Correspondence author: mikari@marum.de ${ }^{3}$ Current address: MARUM, Center for Marine Environmental Sciences, Universität Bremen, 28359 Bremen, Germany.

${ }^{4}$ Department of Geoscience, University of Wisconsin-Madison, Madison WI 53706, USA.

\section{Abstract}

We conducted shearing tests on samples spanning key fault zones recovered from Integrated Ocean Drilling Program (IODP) Sites C0004 and C0007 from Expedition 316 to the Nankai Trough offshore Japan. Results of slide-hold-slide and normal stress stepping procedures allow quantification of frictional healing, time-dependent compaction, and compressibility of sheared gouge layers. Samples were sheared as thin layers in the double-direct shear configuration at $25^{\circ} \mathrm{C}$ in a true-triaxial pressure vessel at constant effective normal stress of $25 \mathrm{MPa}$ and pore pressure of $5 \mathrm{MPa}$ using a water-based brine saturated with $3.5 \mathrm{wt} \% \mathrm{NaCl}$. We monitored the poromechanical drainage state during shear by holding the pore pressure at the upstream end of the sample at $5 \mathrm{MPa}$ while monitoring the downstream pore pressure. Friction constitutive behavior was determined using slide-hold-slide tests in which hold times ranged from 1 to $1000 \mathrm{~s}$. Frictional healing rates range from $\sim 0.003$ to 0.008 per decade, with slightly higher rates measured for samples from Site C0004 than from Site C0007. Both sites exhibit similar compaction rates of $\sim 0.002-0.007$ per decade during holds. Both frictional healing and compaction correlate very well with the logarithm of hold time, with $R^{2}>0.95$. For Site C0004 samples, compressibility was found to be $\sim 1-4$ $\mathrm{GPa}^{-1}$. At Site C0004, compaction rates and compressibility are elevated in the vicinity of the fault zone. At Site C0007, healing rates decrease, and compaction rates increase, with increasing depth.

\section{Introduction}

Geomechanical measurements of sediment deformation are essential for understanding sediment dynamics and faulting processes in convergent margins. During the interseismic period, faults build up stress that is relieved during earthquakes. Here, we employ slide-hold-slide tests during 16 friction experiments in order to simulate the seismic cycle (Dieterich, 1972). From these experiments, we extract rates of frictional healing and associated rates of compaction during hold periods. We also measure the compressibility and Young's modulus of the sheared, saturated sediment, which are basic and important elastic parameters. Hydrologic properties of rock and sediment, for example, are controlled by the elastic response of a porous media to applied 
stresses (e.g., Biot, 1941). The samples we tested were recovered during Integrated Ocean Drilling Program (IODP) Expedition 316, part of the Nankai Trough Seismogenic Zone Experiment (NanTroSEIZE) project, in 2007-2008. During this expedition, several sites were drilled and cored along a transect offshore of the Kii Peninsula, Japan (Fig. F1), to investigate shallow fault zones. We studied samples from two sites: IODP Site C0004, which sampled the shallow portion of a major out-of-sequence thrust fault (the megasplay fault), and IODP Site C0007, which sampled the frontal thrust region near the toe of the accretionary prism (Fig. F2).

\section{Sample descriptions Site $\mathrm{COO04}$}

We tested eight samples from the megasplay fault zone at Site C0004 (see the "Expedition 316 Site C0004" chapter [Expedition 316 Scientists, 2009a]), including two samples from the accretionary prism (hanging wall), four samples from within the megasplay fault zone, and two samples from underthrust slope sediments that comprise the footwall (Table T1). Sample depths ranged from 119.3 to 357.1 meters below seafloor (mbsf); the megasplay fault zone is located between 258.0 and 307.5 mbsf. Within the depth interval of our samples, total clay mineral content ranges between $\sim 40$ and $70 \mathrm{wt} \%$ and combined quartz and plagioclase content ranges from $\sim 25$ to 55 wt\% (see the "Expedition 316 Site C0004" chapter [Expedition 316 Scientists, 2009a]). One hanging wall sample (from Section 316-C0004C-15X-2) and one footwall sample (from Section 316-C0004D-47R-2) were trimmed from whole-round cores and tested as intact wafers. All other samples from this site were dried at a low temperature of $\sim 40^{\circ} \mathrm{C}$ (to prevent clay mineral transformation that may occur at higher temperatures), powdered with a mortar and pestle, and sieved to a uniform grain size of $<106 \mu \mathrm{m}$. This processing was utilized because many samples, especially those from within the fault, were recovered in brecciated condition.

\section{Site $\mathrm{C0007}$}

We tested eight samples from the frontal thrust region at Site C0007 (see the "Expedition 316 Site C0007" chapter [Expedition 316 Scientists, 2009b]), which were sampled from 103.6 to 437.2 mbsf. Site C0007 penetrated the accretionary prism near the trench, including three fault zones located at 237.5259.3, 341.5-362.3, and 398.5-446.0 mbsf (see the "Expedition 316 Site C0007" chapter [Expedition 316 Scientists, 2009b]). We tested one sample from the shallowest fault zone (in Section 316-C0007D-
9R-2) and two from the deepest fault zone (in Sections 316-C0007D-27R-1 and 29R-1). Other samples are from the trench-wedge facies and the lithologic equivalent of the upper Shikoku Basin facies sampled during Ocean Drilling Program (ODP) Leg 190 (Shipboard Scientific Party, 2001) (Table T1). Within the depth interval we studied, combined quartz and plagioclase content ranges from $\sim 50$ to $75 \mathrm{wt} \%$ at the top of the section and decreases with depth to $\sim 30$ $\mathrm{wt} \%$, whereas clay content is $\sim 25-50 \mathrm{wt} \%$ at the top of this section and increases to nearly $70 \mathrm{wt} \%$ by $\sim 360$ mbsf. Three samples from this site were tested as intact wafers trimmed from whole-round cores. Other samples were tested either as powders (which were rehydrated in the sample assembly), remolded wet (cold-pressed into the sample assembly), or tested as breccia with no additional sample preparation (Table T1).

\section{Experimental methods}

We conducted experiments using a biaxial testing apparatus with servo-hydraulic control under truetriaxial stress conditions and controlled pore pressure (Fig. F3). Samples were sheared as $5.4 \mathrm{~cm} \times 5.7$ $\mathrm{cm}$ layers with thicknesses ranging from $\sim 1$ to $4 \mathrm{~mm}$ under load. Samples were jacketed, subjected to confining pressure, and saturated with $3.5 \mathrm{wt} \% \mathrm{NaCl}$ brine as pore fluid. Effective normal stress was maintained at $25 \mathrm{MPa}$ and includes the combined effects of confining pressure $\left(P_{c}\right)$, externally applied normal load, and pore pressure $\left(P_{\mathrm{p}}\right)$. This value of effective stress was chosen for two main reasons: (1) it simulates effective stress conditions near the updip limit of the seismogenic zone (Moore and Saffer, 2001) and (2) it facilitates comparison with our previous experimental work using simulated clay-rich fault gouge (Ikari et al., 2009). The specimens were sheared between steel forcing blocks in the geometry shown in Figure F3. During shear, $P_{\mathrm{c}}$ was held constant at $6 \mathrm{MPa}$, pore pressure at the upstream end of the sample $\left(P_{\mathrm{pa}}\right)$ was held constant at $5 \mathrm{MPa}$, and the downstream pore pressure $\left(P_{\mathrm{pb}}\right)$ was set to a no-flow (undrained) condition in order to monitor pore pressure in the layer (e.g., Ikari et al., 2009).

In each experiment, shear was implemented as a displacement rate boundary condition $(11 \mu \mathrm{m} / \mathrm{s})$ at the gouge layer boundary. The resulting shear stress $(\tau)$ was measured and the coefficient of sliding friction ( $\mu$ ) was calculated by (Handin, 1969):

$$
\tau=\mu \sigma_{\mathrm{n}}{ }^{\prime}+c
$$

where

$$
c \text { = cohesion (assumed to be negligible) and }
$$




\section{$\sigma_{\mathrm{n}}{ }^{\prime}=$ effective normal stress computed using the average of the pore pressures at the drained and undrained boundaries.}

After attainment of steady-state shear stress (typically at a shear strain of $\sim 5$ ), the velocity was increased step-wise in half-order of magnitude increments within the range $0.03-100 \mu \mathrm{m} / \mathrm{s}$ in order to measure friction constitutive parameters, the results of which are reported by Ikari and Saffer (2011). This was followed by a slide-hold-slide sequence performed to measure the frictional healing parameters reported here. Records of shear stress during shearing are shown in Figures F4 and F5. During each hold, the vertical ram was held stationary for prescribed hold times of $1,3,10,30,100,300$, or $1000 \mathrm{~s}$, between which the sample was sheared for a boundary displacement of $500 \mu \mathrm{m}$ at $10 \mu \mathrm{m} / \mathrm{s}$. Upon reinitiating shear, friction reaches a peak value $\left(\mu_{\text {peak }}\right)$ then declines to its prehold steady-state value $\left(\mu_{s s}\right)$ (Fig. F6). We measured the change in friction $(\Delta \mu)$ after each hold:

$$
\Delta \mu=\mu_{\text {peak }}-\mu_{\text {ss }}
$$

The slope of $\Delta \mu$ versus the logarithm of hold time is the healing rate, here denoted as $\beta$ (per decade, or tenfold time increase) (Marone, 1998). Here, we report $\beta$ for hold times of $10-1000 \mathrm{~s}$ to avoid biasing due to nonlinearity at very low hold times. We were also able to make quasistatic compaction measurements $(\Delta h)$ during the hold period (Fig. F6). We report compaction during hold periods as normal strain $(\varepsilon)$ :

$$
\varepsilon=\Delta h / h,
$$

where $h$ is the instantaneous layer thickness immediately prior to a hold. Compaction rates were calculated using the slope of $\varepsilon$ versus the logarithm of hold time, also over the range 10-1000 s.

For samples from Site C0004, after shearing we cycled the applied normal stress in $\sim 6 \mathrm{MPa}$ steps, in order to independently measure sample compressibility $(C)\left(\mathrm{MPa}^{-1}\right)$ (Fig. F7). From each step we measured the normal strain induced by a change in effective normal stress, which is the Young's modulus (E) (MPa) (Jaeger et al., 2007):

$$
E=\Delta \sigma_{\mathrm{n}}{ }^{\prime} / \varepsilon
$$

The compressibility is the inverse of the bulk modulus $(K)(\mathrm{MPa})$, which is related to the Young's modulus by Poisson's ratio (v) (Gercek, 2007; Jaeger et al., 2007):

$$
1 / C=K=E /[3(1-2 v)]
$$

We did not explicitly measure $K$ in these experiments; however, we assume a value of $v=\sim 0.33$, which is appropriate for claystones (Gercek, 2007). In this case, $K=E$ and the compressibility may be calculated as the inverse of the Young's modulus. In addition, we note that for a thin layer of frictional material, small perturbations in layer thickness occur at constant nominal contact area and thus changes in layer thickness are directly related to changes in volume. Under this assumption, $K=E$. For each sample, we fit multiple stress steps and the origin to compute the compressibility values.

\section{Results}

\section{Frictional healing}

Frictional healing exhibits a linear relationship with the logarithm of hold time for holds longer than $10 \mathrm{~s}$ for samples from both Sites $\mathrm{C0004}$ and $\mathrm{C0007}$ (Figs. F8, F9). For $1000 \mathrm{~s}$ holds, $\Delta \mu$ ranges from 0.009 to 0.023 for samples from Site C0004 and from 0.008 to 0.020 for samples from Site C0007 (Tables T2, T3). Healing rates range from $\sim 0.005$ to 0.008 per decade for samples from Site C0004 and are slightly lower for samples from Site C0007, ranging from $~ 0.003$ to 0.007 per decade (Table T4). The healing rate exhibits a weakly increasing trend with depth at Site C0004 and a decreasing trend with depth at Site C0007 (Figs. F8, F9). There is little difference between sample healing rates from within fault zones compared to samples from wall rock.

\section{Compaction}

Compaction rate also generally exhibits a linear relation with the logarithm of hold time for holds longer than $\sim 10$ s (Figs. F10, F11). However, some samples exhibited slight nonlinearity, showing concave upward trends (Fig. F10). For 1000 s holds, normal strain $(\varepsilon)$ from compaction ranges from 0.005 to 0.016 at both Sites C0004 and C0007 (Tables T2, T3). Compaction rates for the two sites are also similar, ranging from $\sim 0.002$ to 0.007 per decade. Compaction data as a function of logarithmic hold time in the 10-1000 s range are well fit linearly, with $R^{2}>$ 0.95 for both sites, including those that show some nonlinearity (Table T4). Compaction rates decrease with increasing distance from the fault zone at Site C0004 and appear to increase with depth at Site C0007.

\section{Compressibility}

Compressibility was calculated from linear fits to layer-normal strains in response to changes in effective normal stress; we conducted these experiments 
only for specimens from Site C0004 (Fig. F12; Table T5). Compressibility values range from 0.89 to 3.85 $\mathrm{GPa}^{-1}$, and the corresponding Young's modulus ranges from 0.26 to $1.12 \mathrm{GPa}$ (Table T6). Compressibility is highest within the fault zone but otherwise does not exhibit any clear trend downsection (Fig. F12).

\section{Acknowledgments}

This work was supported by National Science Foundation awards EAR-0746192, EAR-0752114, and OCE-0648331 to D. Saffer and C. Marone. Samples were provided by the Integrated Ocean Drilling Program (IODP) and collected during Expedition 316. We thank Liz Screaton and an anonymous reviewer for helpful suggestions, which improved this manuscript.

\section{References}

Biot, M.A., 1941. General theory of three-dimensional consolidation. J. Appl. Phys., 12(2):155-164. doi:10.1063/ 1.1712886

Dieterich, J.H., 1972. Time-dependent friction in rocks. J. Geophys. Res., [Solid Earth], 77(20):3690-3697. doi:10.1029/JB077i020p03690

Expedition 316 Scientists, 2009a. Expedition 316 Site C0004. In Kinoshita, M., Tobin, H., Ashi, J., Kimura, G., Lallemant, S., Screaton, E.J., Curewitz, D., Masago, H., Moe, K.T., and the Expedition 314/315/316 Scientists, Proc. IODP, 314/315/316: Washington, DC (Integrated Ocean Drilling Program Management International, Inc.). doi:10.2204/iodp.proc.314315316.133.2009

Expedition 316 Scientists, 2009b. Expedition 316 Site C0007. In Kinoshita, M., Tobin, H., Ashi, J., Kimura, G., Lallemant, S., Screaton, E.J., Curewitz, D., Masago, H., Moe, K.T., and the Expedition 314/315/316 Scientists, Proc. IODP, 314/315/316: Washington, DC (Integrated Ocean Drilling Program Management International, Inc.). doi:10.2204/iodp.proc.314315316.135.2009
Gercek, H., 2007. Poisson's ratio values for rocks. Int. J. Rock Mech. Min. Sci., 44(1):1-13. doi:10.1016/ j.ijrmms.2006.04.011

Handin, J., 1969. On the Coulomb-Mohr failure criterion. J. Geophys. Res., [Solid Earth], 74(22):5343-5348. doi:10.1029/JB074i022p05343

Ikari, M.J., and Saffer, D.M., 2011. Comparison of frictional strength and velocity dependence between fault zones in the Nankai accretionary complex. Geochem., Geophys., Geosyst., 12:Q0AD11. doi:10.1029/ 2010GC003442

Ikari, M.J., Saffer, D.M., and Marone, C., 2009. Frictional and hydrologic properties of a major splay fault system, Nankai subduction zone. Geophys. Res. Lett., 36(20):L20313. doi:10.1029/2009GL040009

Jaeger, J.C., Cook, N.G.W., and Zimmerman, R., 2007. Fundamentals of Rock Mechanics (4th ed.): Malden, MA (Blackwell Publ.).

Kimura, G., Screaton, E.J., Curewitz, D., and the Expedition 316 Scientists, 2008. NanTroSEIZE Stage 1A: NanTroSEIZE shallow megasplay and frontal thrusts. IODP Prel. Rept., 316. doi:10.2204/iodp.pr.316.2008

Marone, C., 1998. The effect of loading rate on static friction and the rate of fault healing during the earthquake cycle. Nature (London, U. K.), 391(6662):69-72. doi:10.1038/34157

Moore, J.C., and Saffer, D., 2001. Updip limit of the seismogenic zone beneath the accretionary prism of southwest Japan: an effect of diagenetic to low-grade metamorphic processes and increasing effective stress. Geology, 29(2):183-186. doi:10.1130/00917613(2001)029<0183:ULOTSZ>2.0.CO;2

Shipboard Scientific Party, 2001. Leg 190 summary. In Moore, G.F., Taira, A., Klaus, A., et al., Proc. ODP, Init. Repts., 190: College Station, TX (Ocean Drilling Program), 1-87. doi:10.2973/odp.proc.ir.190.101.2001

Initial receipt: 18 April 2011

Acceptance: 11 April 2012

Publication: 13 July 2012

MS 314315316-219 
Figure F1. Map of the Nankai area showing the location of drill Sites C0004 and C0007 as well as the rupture areas (dashed boxes) and epicenters (stars) of the 1944 Tonankai and 1946 Nankaido earthquakes (modified from Kimura et al., 2008). EP $=$ Eurasian plate, PSP $=$ Philippine Sea plate, $\mathrm{PP}=$ Pacific plate, NAP $=$ North American plate.

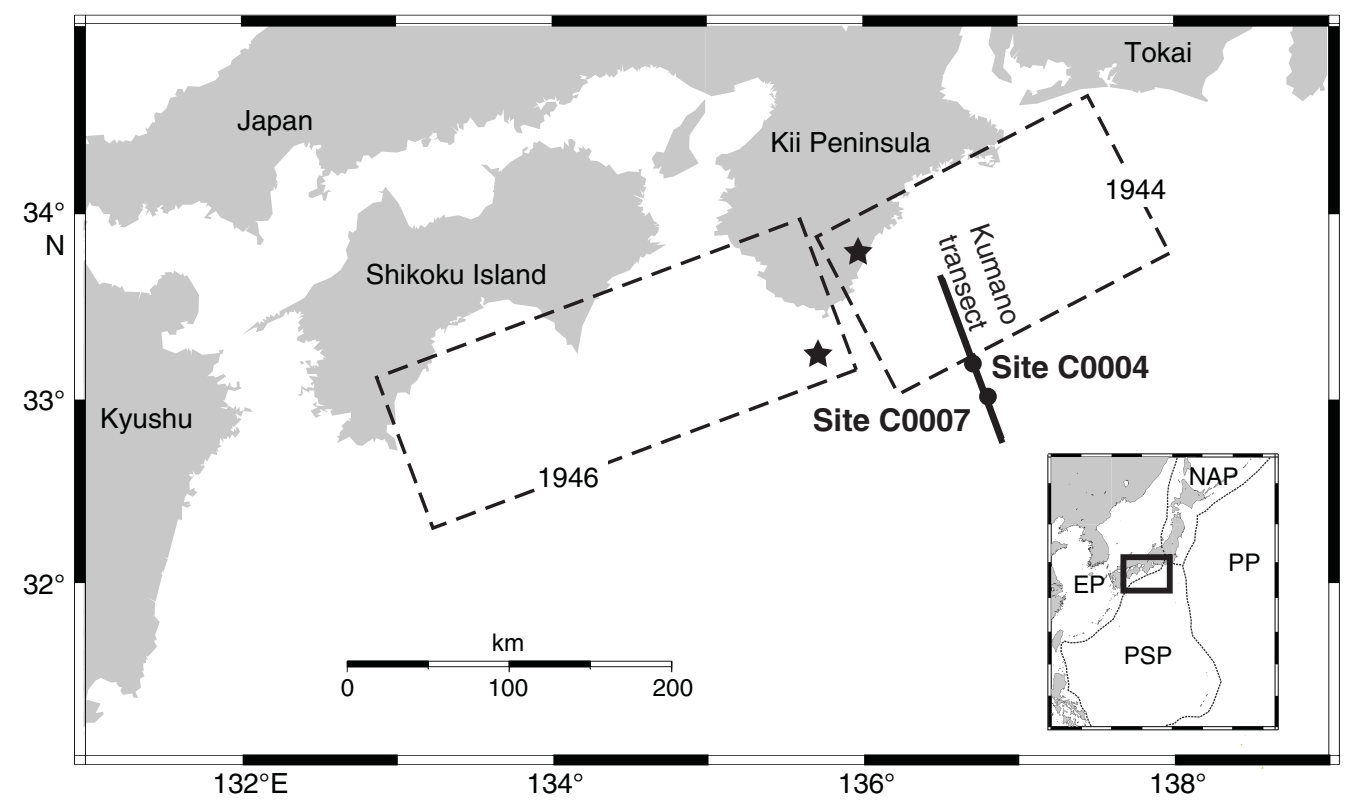


Figure F2. Profile of the accretionary prism along the Kumano transect in Figure F1, showing drill Sites C0004 and C0007 and approximate sampling area (modified from Kimura et al., 2008).

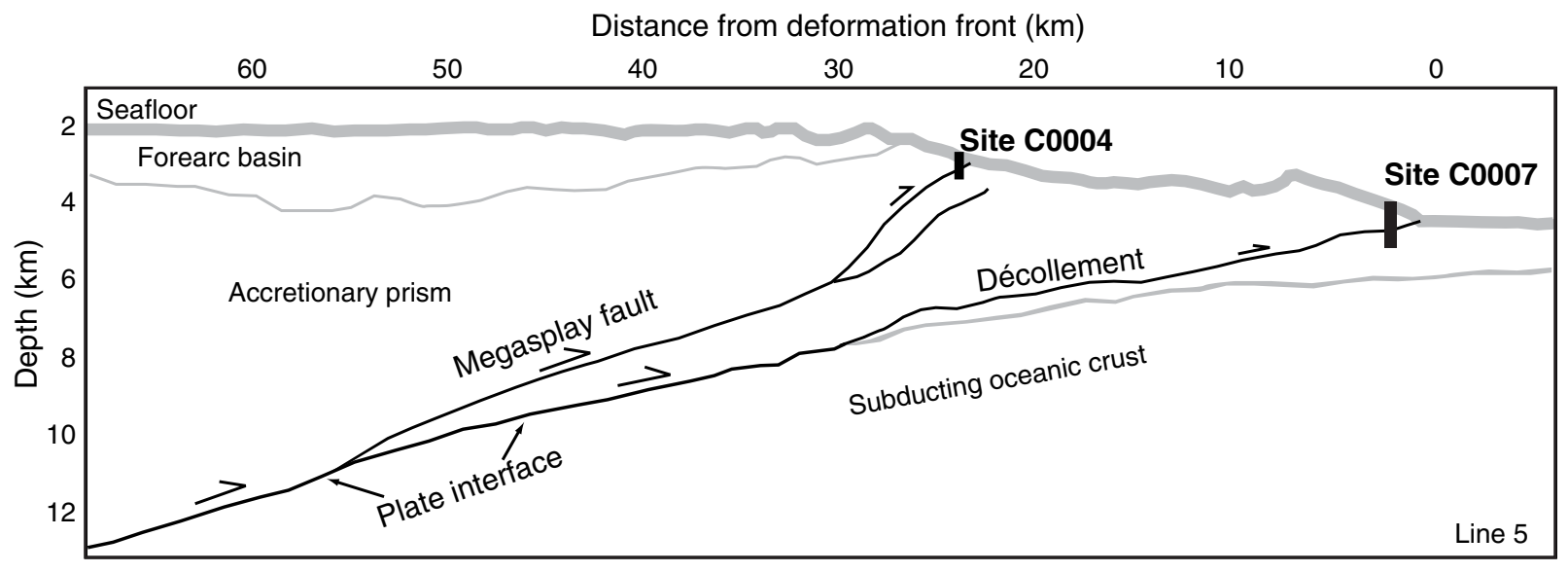



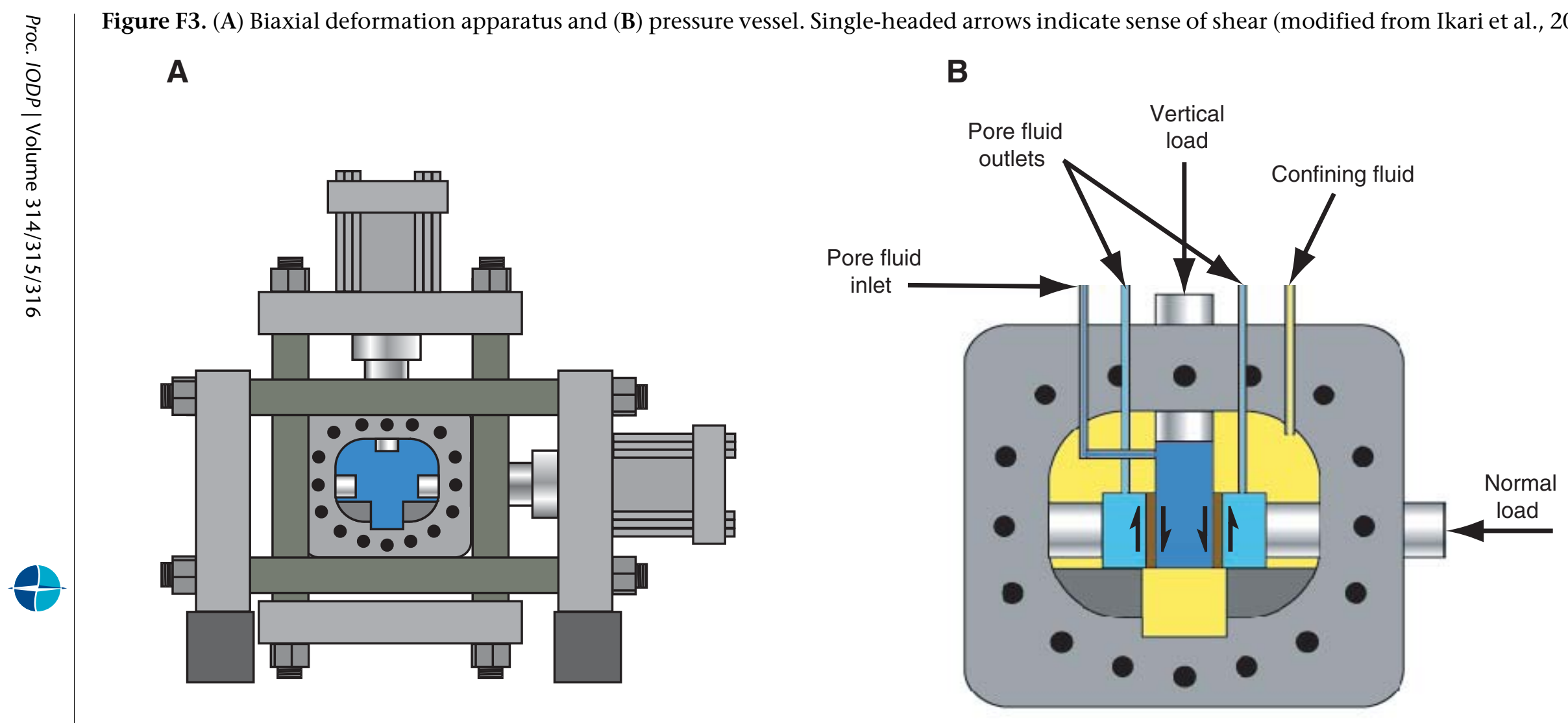
Figure F4. Stress-displacement curves, Site C0004. Slide-hold-slide sequence is indicated in the first plot. (Continued on next page.)
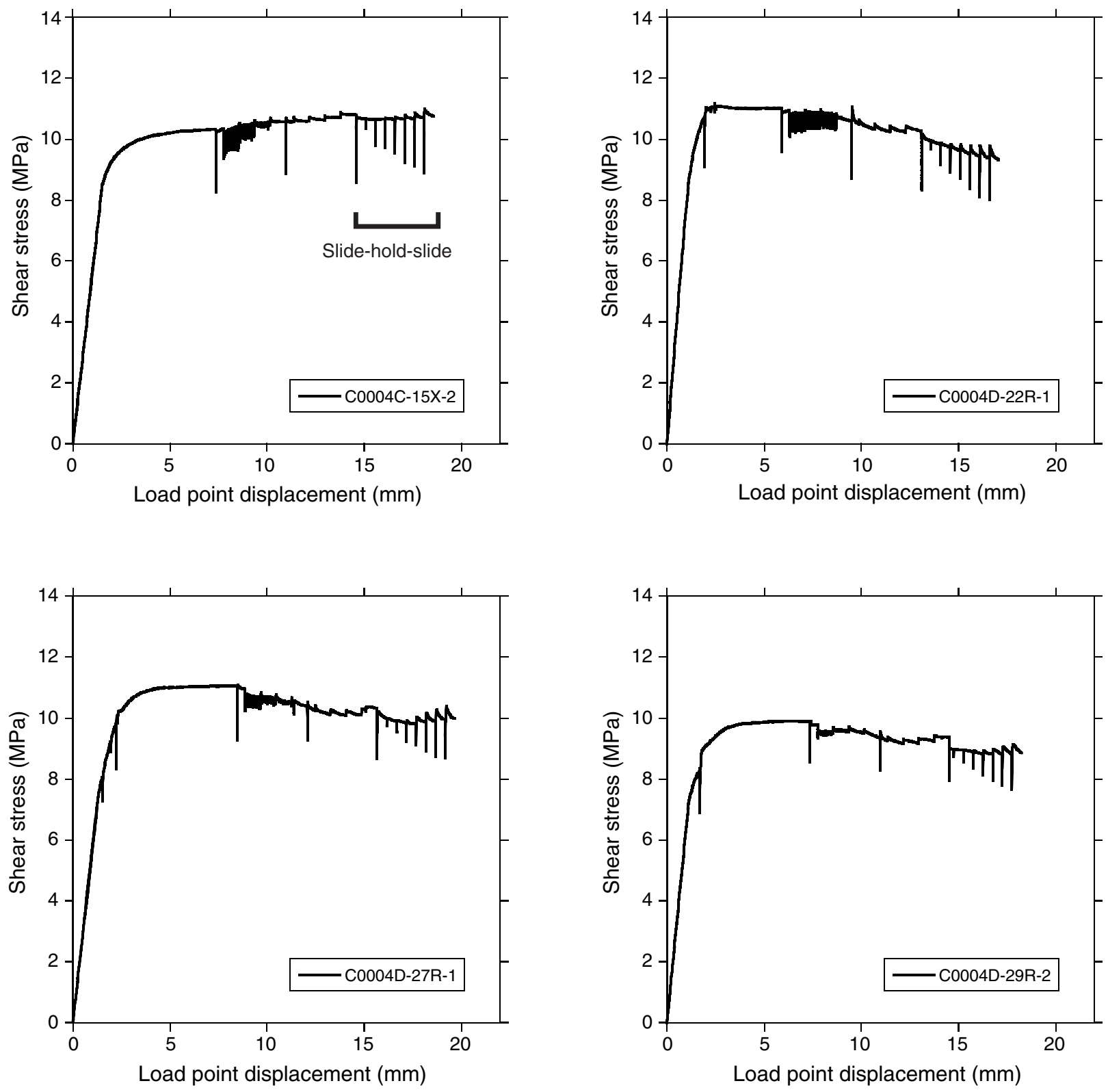
Figure F4 (continued).
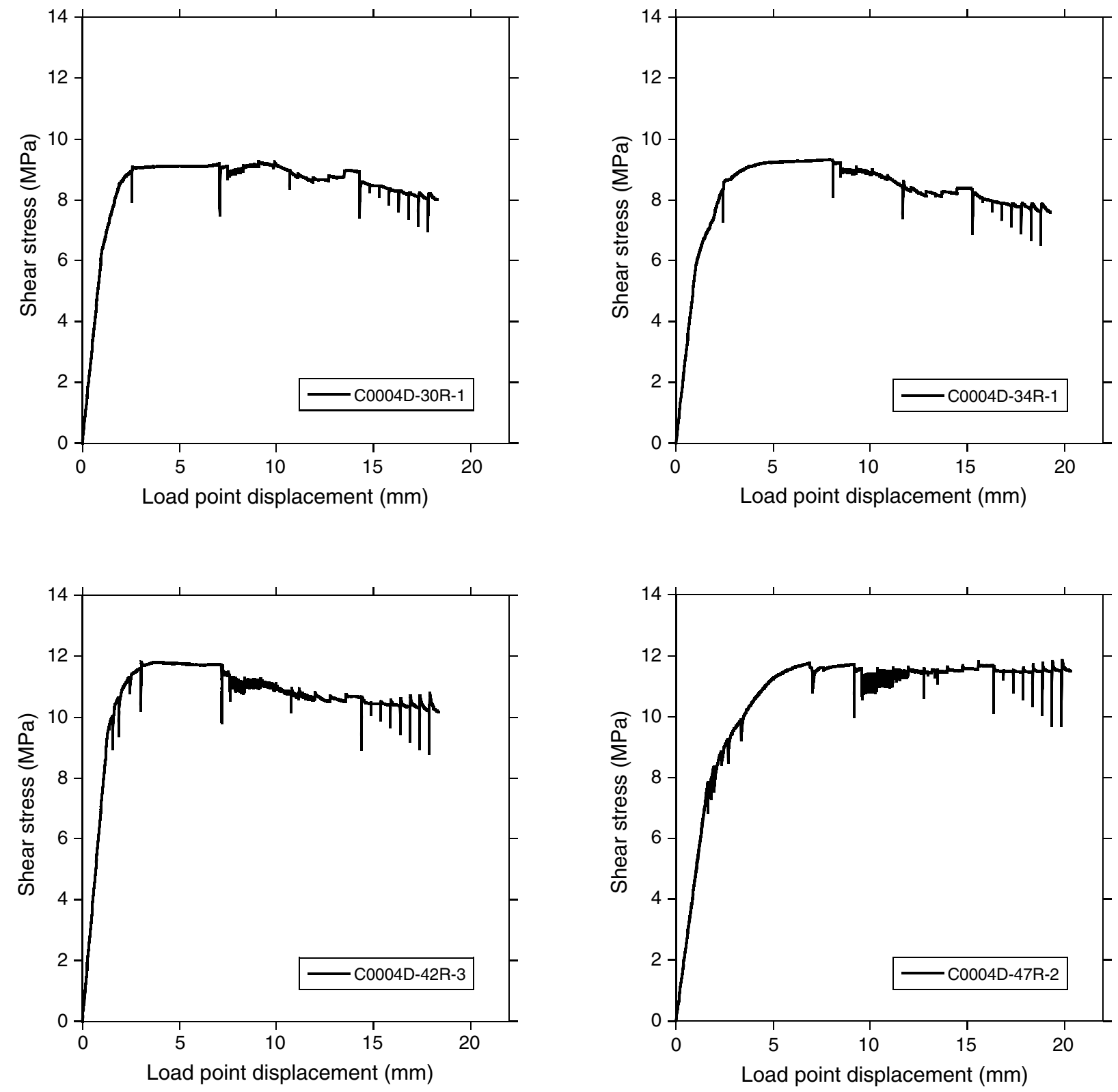
Figure F5. Stress-displacement curves, Site C0007. (Continued on next page.)
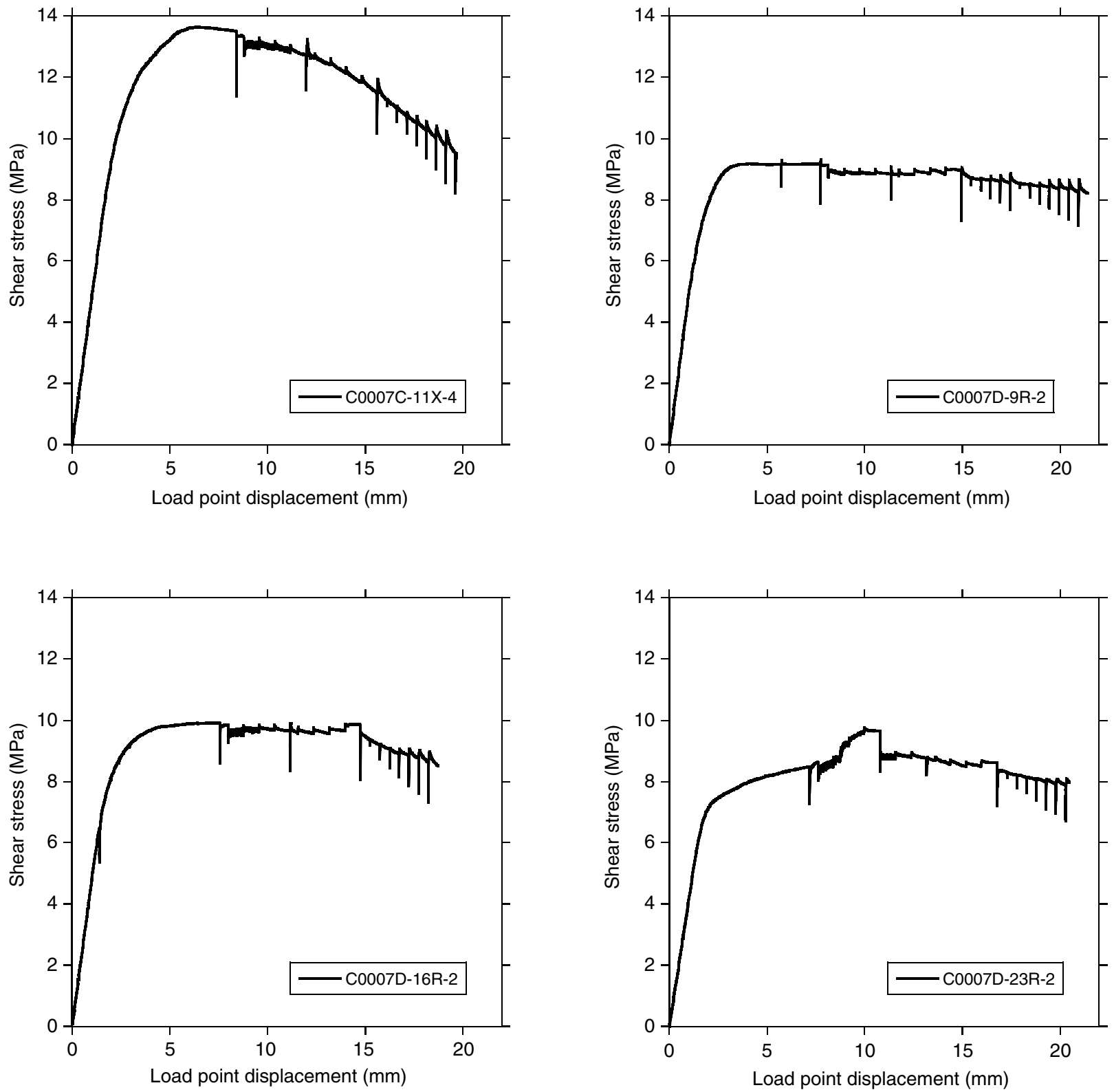
Figure F5 (continued).
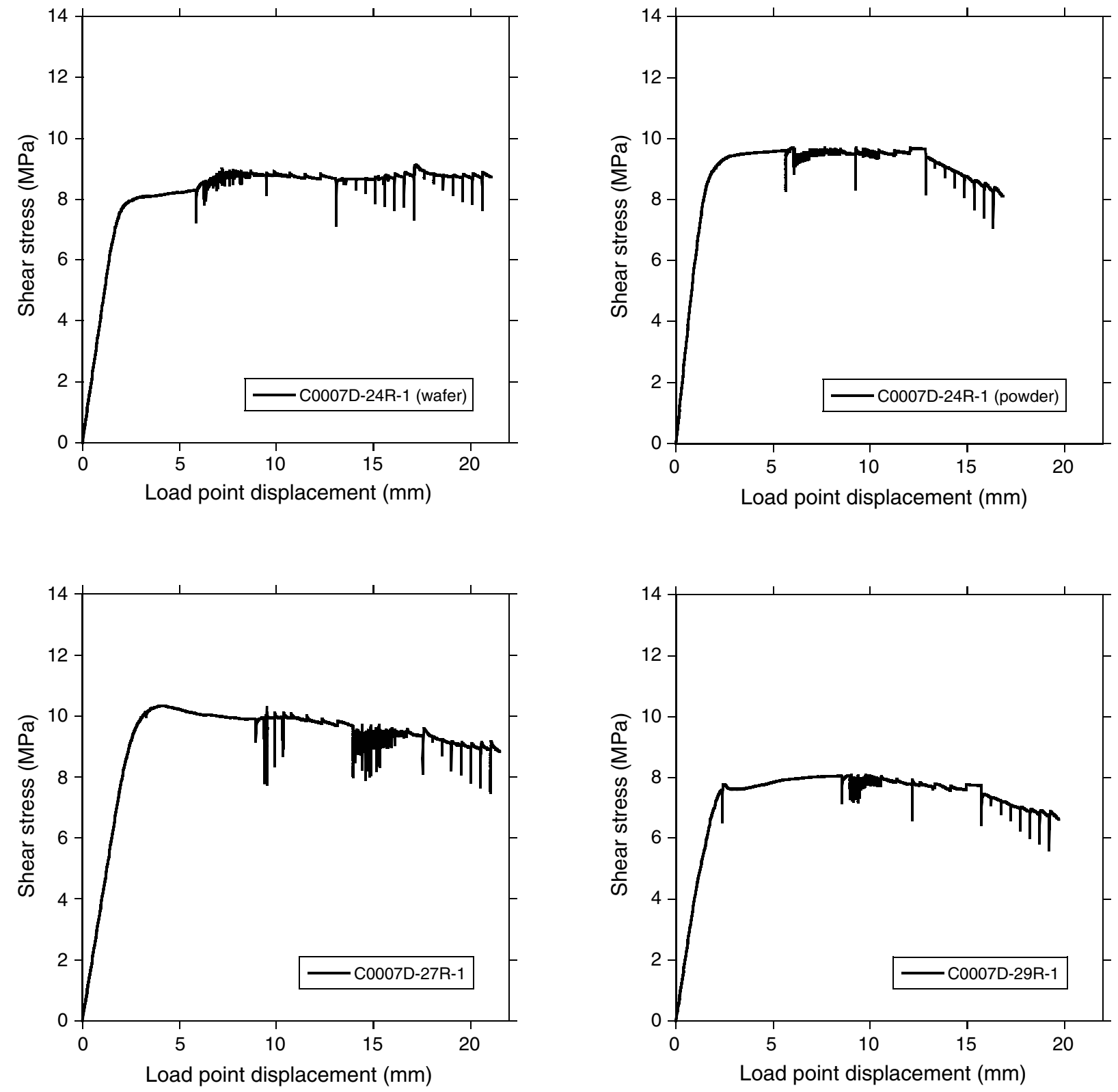
Figure F6. Time series during a slide-hold-slide sequence of (A) coefficient of friction and (B) compaction. Example shown is a $100 \mathrm{~s}$ hold period for Sample 316-C0007D-9R-2. Background compaction rate during sliding is due to geometrical sample thinning that does not affect compaction during the hold period.

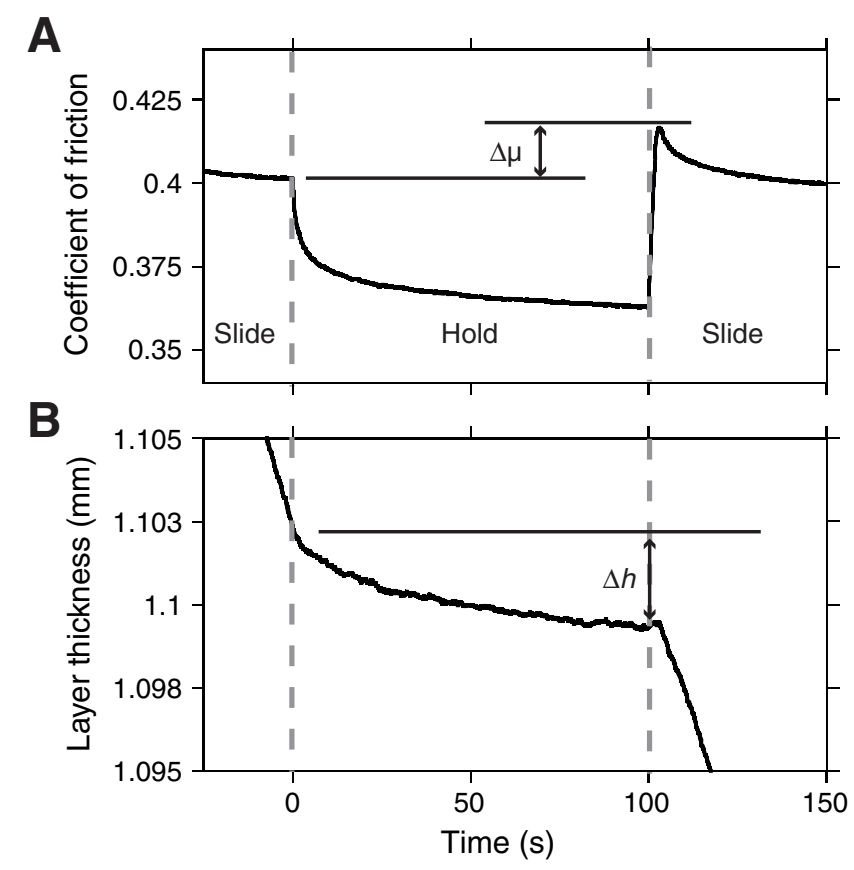


Figure F7. Example of a set of normal stress steps $\left(\Delta \sigma_{n}{ }^{\prime}\right)$ and resulting change in sample layer thickness $(\Delta h)$ used to calculate sediment compressibility and Young's modulus.

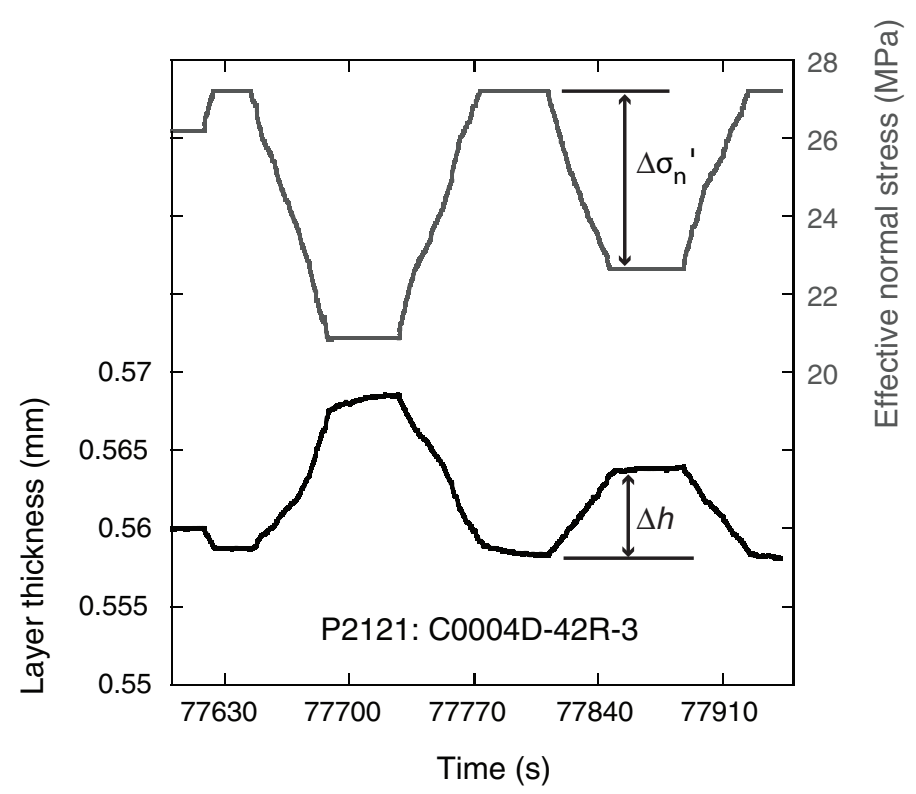


Figure F8. Frictional healing data, Site C0004. A. $\Delta \mu$ as a function of hold time. B. Healing rates as a function of depth.

A

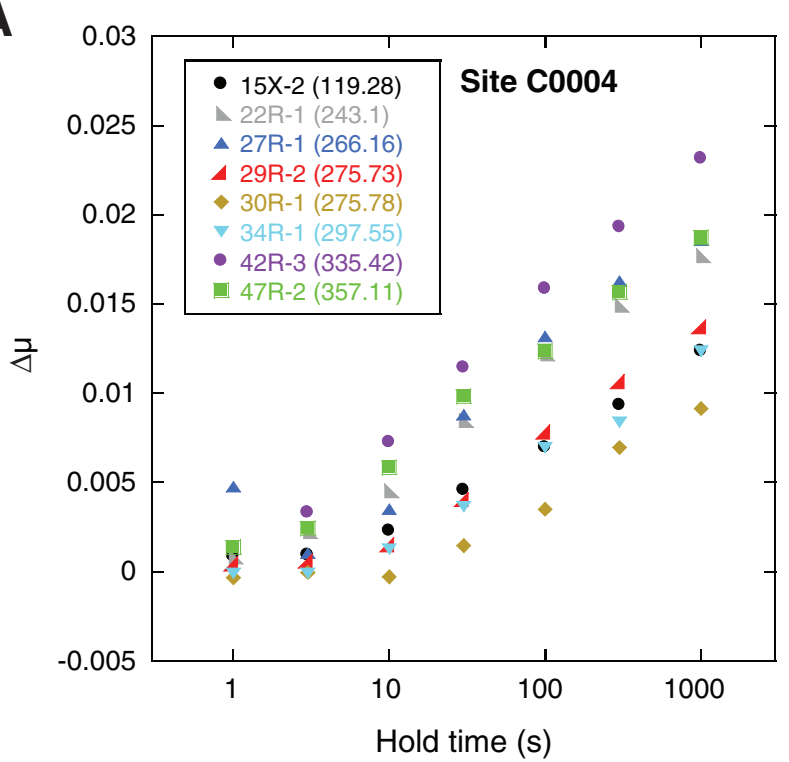

B

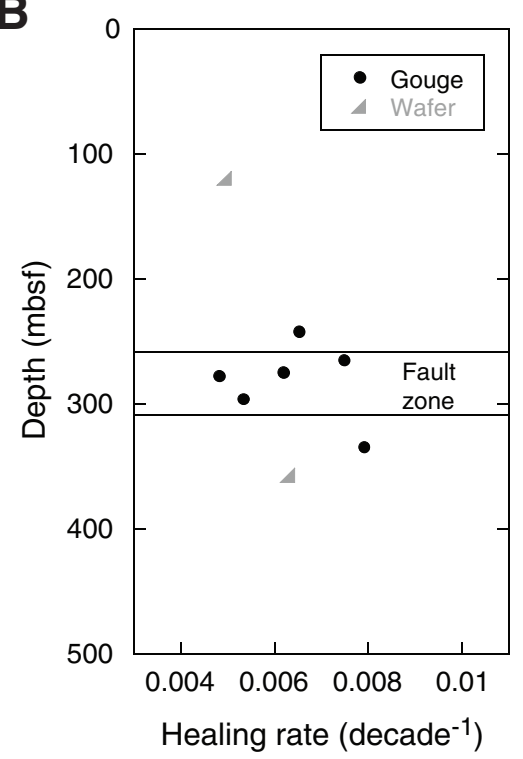


Figure F9. Frictional healing data, Site C0007. A. $\Delta \mu$ as a function of hold time. B. Healing rates as a function of depth.

A

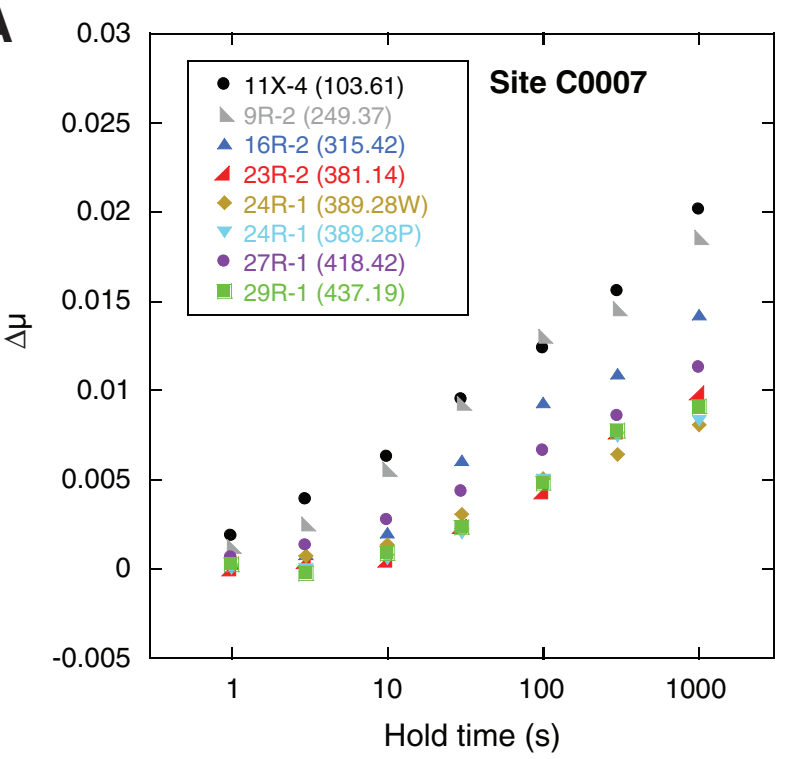

B

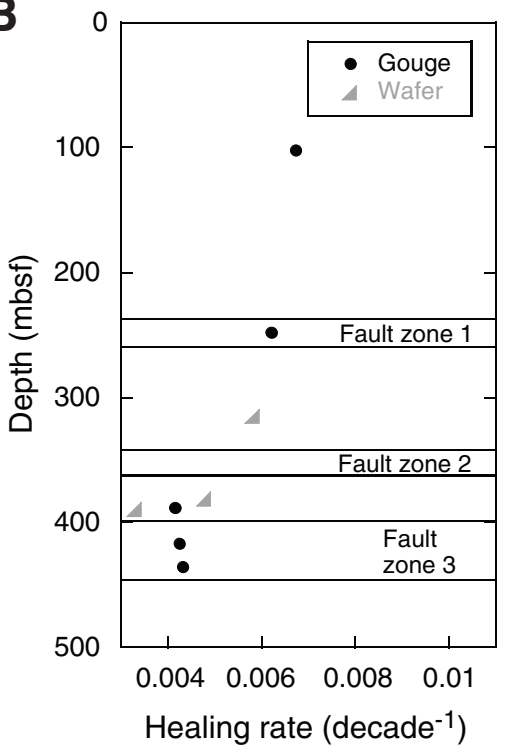


Figure F10. Compaction data, Site C0004. A. $\varepsilon$ as a function of hold time. B. Compaction rates as a function of depth.
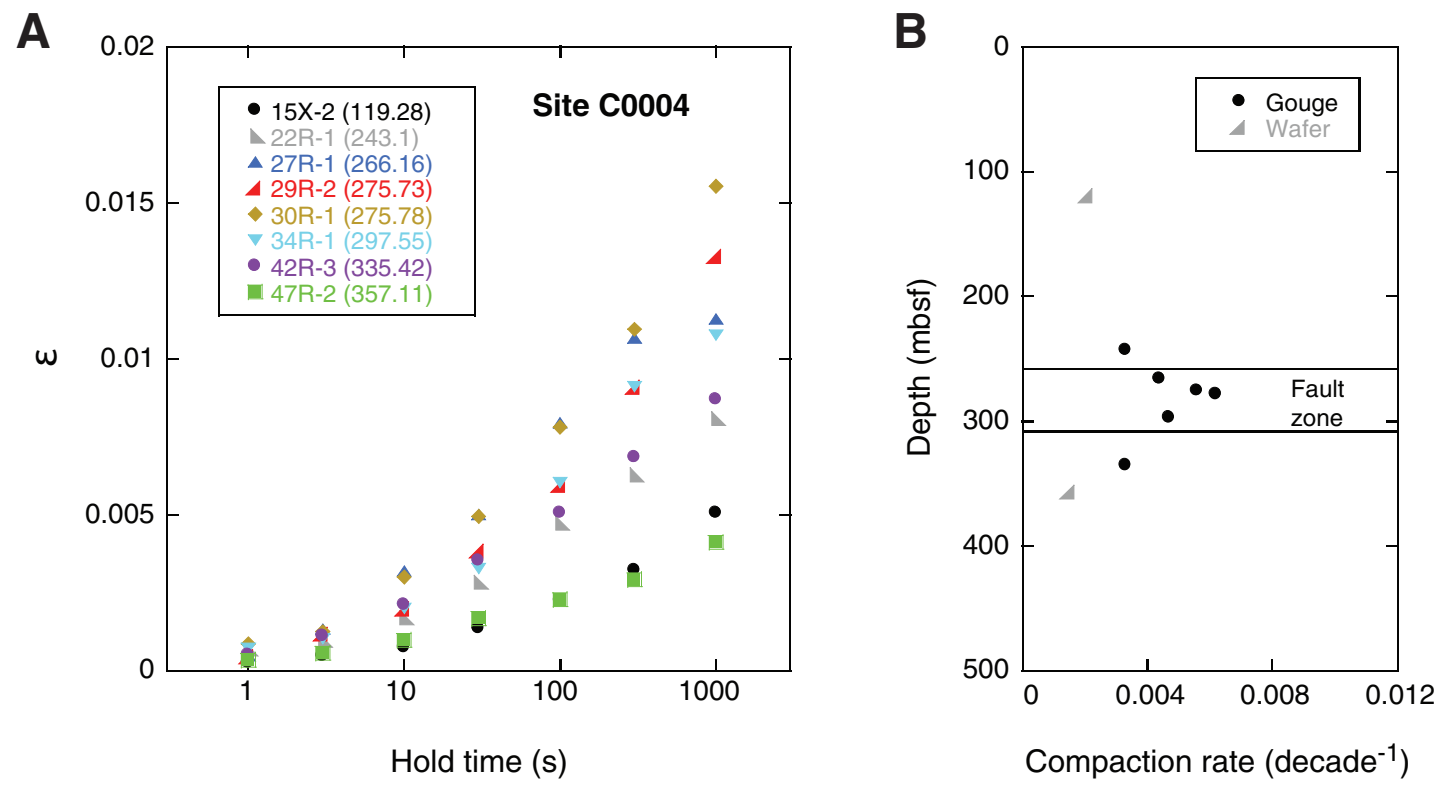
Figure F11. Compaction data, Site C0007. A. $\varepsilon$ as a function of hold time. B. Compaction rates as a function of depth.
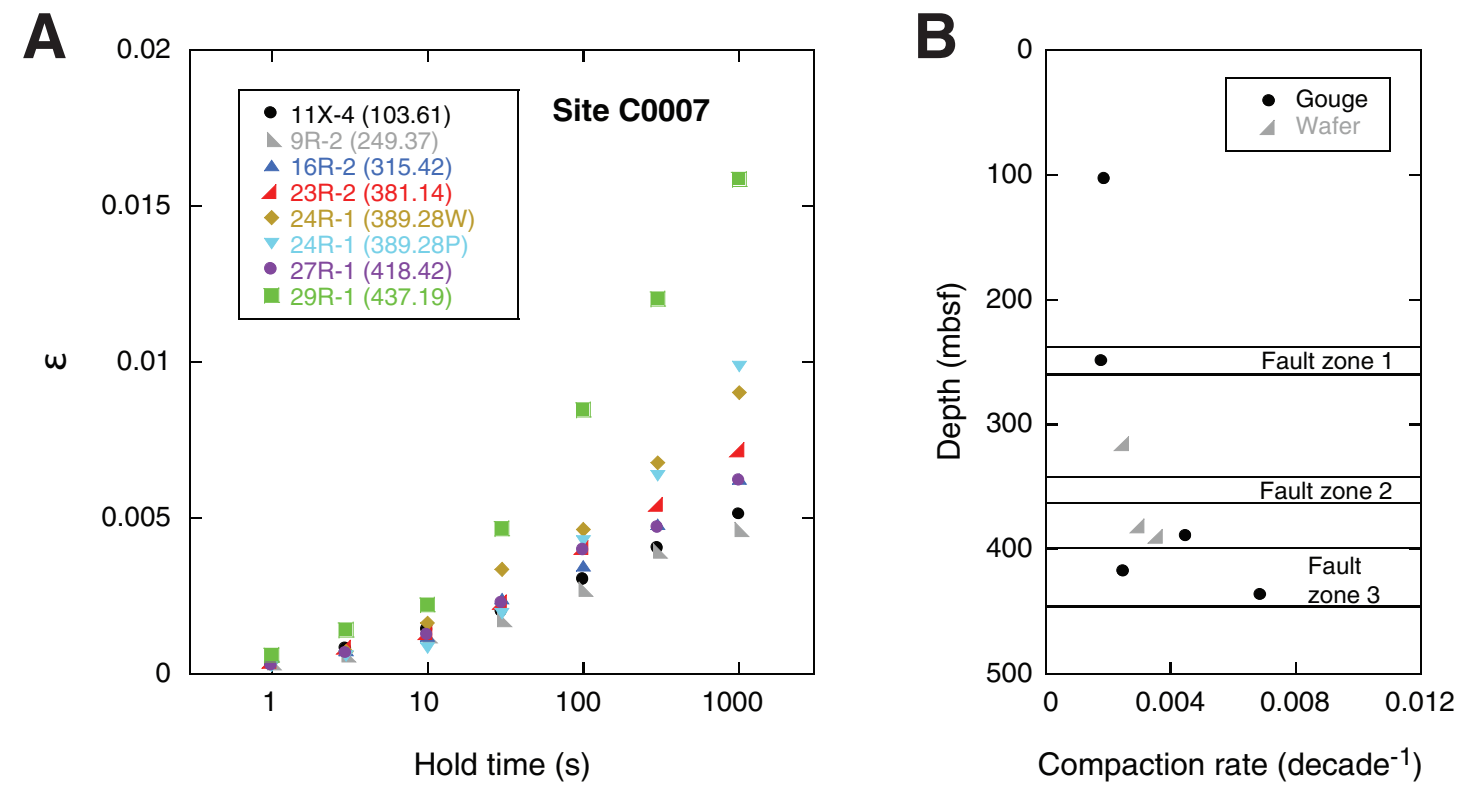
Figure F12. Results of normal stress steps, Site C0004. A. Normal strain as a function of change in effective normal stress. B. Compressibility as a function of depth.
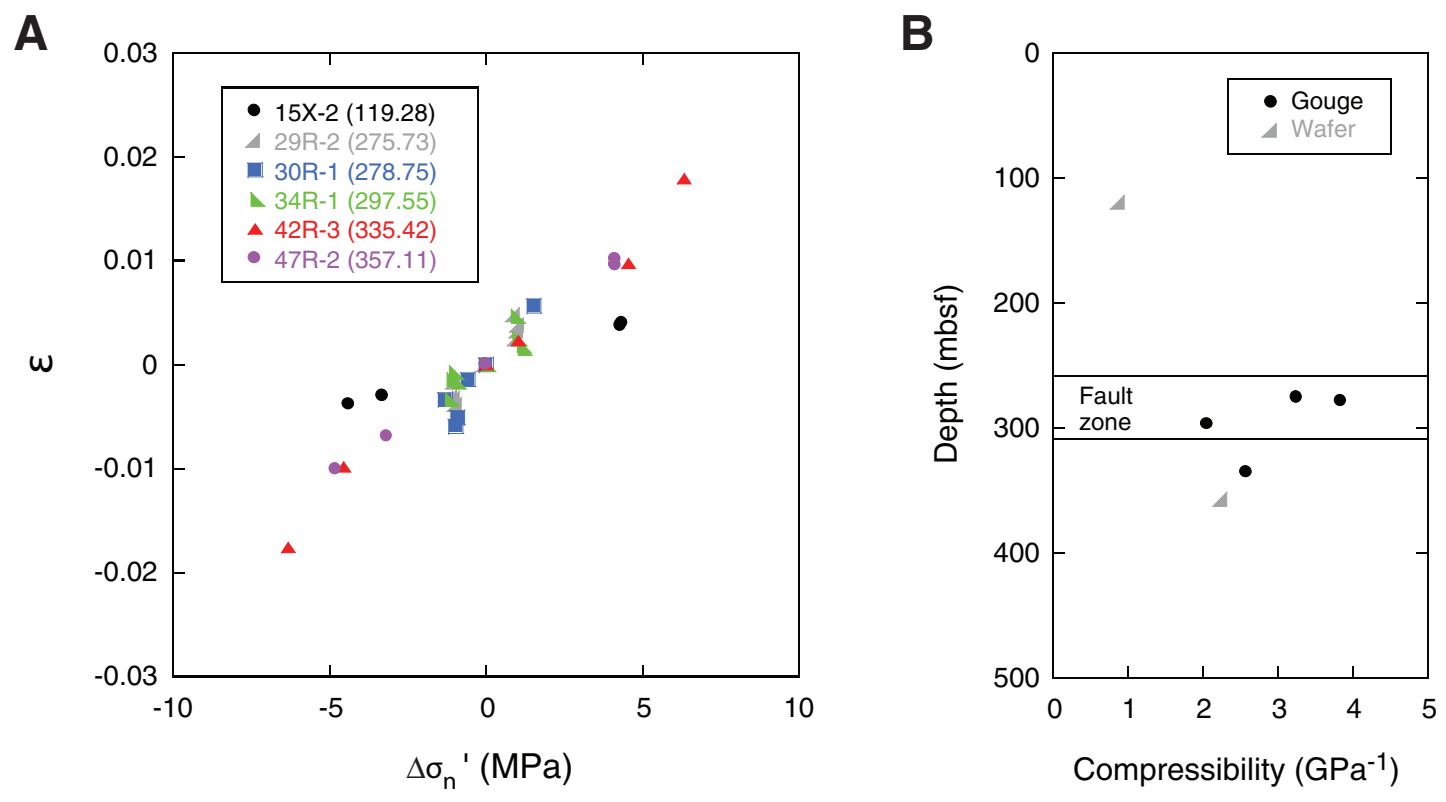
Table T1. Samples tested and experiment parameters.

\begin{tabular}{lccccll}
\hline Experiment & Hole, core, section & $\begin{array}{c}\text { Depth } \\
(\mathrm{mbsf})\end{array}$ & $\begin{array}{c}h_{\mathrm{o}} \\
(\mathrm{mm})\end{array}$ & $\gamma_{\max }$ & \multicolumn{1}{c}{ Stratigraphic location } & State \\
\hline & 316- & & & & & \\
P2118 & C0004C-15X-2 & 119.28 & 2.42 & 6.1 & Accretionary prism & Wafer \\
P2627 & C0004D-22R-1 & 243.10 & 1.39 & 20.5 & Accretionary prism & Powder \\
P2102 & C0004D-27R-1 & 266.16 & 1.14 & 16.0 & Fault zone & Powder \\
P2069 & C0004D-29R-2 & 275.73 & 1.07 & 14.4 & Fault zone & Powder \\
P2067 & C0004D-30R-1 & 278.75 & 0.86 & 19.9 & Fault zone & Powder \\
P2068 & C0004D-34R-1 & 297.55 & 1.06 & 15.7 & Fault zone & Powder \\
P2121 & C0004D-42R-3 & 335.42 & 1.41 & 10.8 & Underthrust slope apron & Powder \\
P2112 & C0004D-47R-2 & 357.11 & 3.88 & 3.7 & Underthrust slope apron & Wafer \\
& 316- & & & & & \\
P2654 & C0007C-11X-4 & 103.61 & 4.58 & 7.0 & Outer trench wedge & Remolded \\
P2777 & C0007D-9R-2 & 249.37 & 2.52 & 14.6 & Fault zone & Remolded \\
P2640 & C0007D-16R-2 & 315.42 & 3.45 & 10.0 & Marginal trench wedge & Wafer \\
P2639 & C0007D 23R-2 & 381.14 & 3.43 & 14.0 & USB facies & Wafer \\
P2655 & C0007D-24R-1 & 389.28 & 3.79 & 21.0 & USB facies & Wafer \\
P2656 & C0007D-24R-1 & 389.28 & 2.20 & 22.3 & USB facies & Powder \\
P2644 & C0007D-27R-1 & 418.42 & 3.59 & 12.4 & Fault zone & Breccia \\
P2641 & C0007D-29R-1 & 437.19 & 2.15 & 29.3 & Fault zone & Powder \\
\hline
\end{tabular}

USB = upper Shikoku Basin. 
Table T2. Slide-hold-slide parameters, Site C0004.

\begin{tabular}{|c|c|c|c|c|c|c|c|}
\hline Experiment & Hole, core, section & $\begin{array}{l}\text { Depth } \\
\text { (mbsf) }\end{array}$ & $\begin{array}{l}\text { Hold } \\
\text { time (s) }\end{array}$ & $\Delta \mu$ & $\begin{array}{c}\Delta h \\
(\mu \mathrm{m})\end{array}$ & $\begin{array}{c}\stackrel{h}{(\mu \mathrm{m})} \\
.\end{array}$ & $\varepsilon$ \\
\hline & 316- & & & & & & \\
\hline P2118 & C0004C-15X-2 & 119.28 & 1 & 0.0009 & 0.3 & 1325.2 & 0.0003 \\
\hline P2118 & C0004C-15X-2 & 119.28 & 3 & 0.0009 & 0.6 & 1304.9 & 0.0005 \\
\hline P2118 & C0004C-15X-2 & 119.28 & 10 & 0.0023 & 1.0 & 1283.9 & 0.0008 \\
\hline P2118 & C0004C-15X-2 & 119.28 & 30 & 0.0046 & 1.7 & 1263.6 & 0.0014 \\
\hline P2118 & C0004C-15X-2 & 119.28 & 100 & 0.0070 & 2.8 & 1243.4 & 0.0023 \\
\hline P2118 & C0004C-15X-2 & 119.28 & 300 & 0.0094 & 4.0 & 1222.7 & 0.0032 \\
\hline P2118 & C0004C-15X-2 & 119.28 & 1000 & 0.0124 & 6.1 & 1202.0 & 0.0051 \\
\hline P2627 & C0004D-22R-1 & 243.10 & 1 & 0.0009 & 0.5 & 679.8 & 0.0007 \\
\hline P2627 & C0004D-22R-1 & 243.10 & 3 & 0.0023 & 0.7 & 665.4 & 0.0010 \\
\hline P2627 & C0004D-22R-1 & 243.10 & 10 & 0.0045 & 1.1 & 651.1 & 0.0017 \\
\hline P2627 & C0004D-22R-1 & 243.10 & 30 & 0.0085 & 1.8 & 637.1 & 0.0028 \\
\hline P2627 & C0004D-22R-1 & 243.10 & 100 & 0.0122 & 3.0 & 623.2 & 0.0047 \\
\hline P2627 & C0004D-22R-1 & 243.10 & 300 & 0.0149 & 3.8 & 609.2 & 0.0063 \\
\hline P2627 & C0004D-22R-1 & 243.10 & 1000 & 0.0177 & 4.8 & 595.0 & 0.0081 \\
\hline P2102 & C0004D-27R-1 & 266.16 & 1 & 0.0048 & 0.2 & 491.8 & 0.0005 \\
\hline P2102 & C0004D-27R-1 & 266.16 & 3 & 0.0010 & 0.6 & 482.1 & 0.0013 \\
\hline P2102 & C0004D-27R-1 & 266.16 & 10 & 0.0035 & 1.5 & 471.8 & 0.0032 \\
\hline P2102 & C0004D-27R-1 & 266.16 & 30 & 0.0088 & 2.3 & 460.5 & 0.0050 \\
\hline P2102 & C0004D-27R-1 & 266.16 & 100 & 0.0132 & 3.6 & 449.5 & 0.0079 \\
\hline P2102 & C0004D-27R-1 & 266.16 & 300 & 0.0163 & 4.7 & 437.6 & 0.0107 \\
\hline P2102 & C0004D-27R-1 & 266.16 & 1000 & 0.0186 & 4.8 & 425.4 & 0.0113 \\
\hline P2069 & C0004D-29R-2 & 275.73 & 1 & 0.0004 & 0.2 & 517.2 & 0.0005 \\
\hline P2069 & C0004D-29R-2 & 275.73 & 3 & 0.0006 & 0.6 & 506.1 & 0.0012 \\
\hline P2069 & C0004D-29R-2 & 275.73 & 10 & 0.0015 & 1.0 & 494.9 & 0.0020 \\
\hline P2069 & C0004D-29R-2 & 275.73 & 30 & 0.0040 & 1.9 & 483.7 & 0.0038 \\
\hline P2069 & C0004D-29R-2 & 275.73 & 100 & 0.0078 & 2.8 & 472.0 & 0.0059 \\
\hline P2069 & C0004D-29R-2 & 275.73 & 300 & 0.0107 & 4.2 & 460.2 & 0.0091 \\
\hline P2069 & C0004D-29R-2 & 275.73 & 1000 & 0.0137 & 5.9 & 447.2 & 0.0133 \\
\hline P2067 & C0004D-30R-1 & 278.75 & 1 & -0.000313 & 0.3 & 359.6 & 0.0009 \\
\hline P2067 & C0004D-30R-1 & 278.75 & 3 & -0.0000562 & 0.4 & 350.6 & 0.0012 \\
\hline P2067 & C0004D-30R-1 & 278.75 & 10 & -0.000265 & 1.0 & 341.5 & 0.0030 \\
\hline P2067 & C0004D-30R-1 & 278.75 & 30 & 0.0015 & 1.6 & 331.5 & 0.0050 \\
\hline P2067 & C0004D-30R-1 & 278.75 & 100 & 0.0035 & 2.5 & 321.7 & 0.0078 \\
\hline P2067 & C0004D-30R-1 & 278.75 & 300 & 0.0070 & 3.4 & 311.4 & 0.0109 \\
\hline P2067 & C0004D-30R-1 & 278.75 & 1000 & 0.0091 & 4.7 & 300.6 & 0.0155 \\
\hline P2068 & C0004D-34R-1 & 297.55 & 1 & -0.0000922 & 0.4 & 496.4 & 0.0007 \\
\hline P2068 & C0004D-34R-1 & 297.55 & 3 & -0.000086695 & 0.5 & 485.7 & 0.0010 \\
\hline P2068 & C0004D-34R-1 & 297.55 & 10 & 0.0013 & 1.0 & 474.9 & 0.0020 \\
\hline P2068 & C0004D-34R-1 & 297.55 & 30 & 0.0036 & 1.5 & 463.7 & 0.0033 \\
\hline P2068 & C0004D-34R-1 & 297.55 & 100 & 0.0070 & 2.7 & 452.3 & 0.0060 \\
\hline P2068 & C0004D-34R-1 & 297.55 & 300 & 0.0083 & 4.0 & 441.0 & 0.0091 \\
\hline P2068 & C0004D-34R-1 & 297.55 & 1000 & 0.0124 & 4.6 & 428.8 & 0.0108 \\
\hline P2121 & C0004D-42R-3 & 335.42 & 1 & 0.0014 & 0.3 & 679.4 & 0.0005 \\
\hline P2121 & C0004D-42R-3 & 335.42 & 3 & 0.0033 & 0.7 & 664.1 & 0.0011 \\
\hline P2121 & C0004D-42R-3 & 335.42 & 10 & 0.0072 & 1.4 & 649.2 & 0.0021 \\
\hline P2121 & C0004D-42R-3 & 335.42 & 30 & 0.0114 & 2.2 & 634.3 & 0.0035 \\
\hline P2121 & C0004D-42R-3 & 335.42 & 100 & 0.0159 & 3.1 & 619.4 & 0.0051 \\
\hline P2121 & C0004D-42R-3 & 335.42 & 300 & 0.0193 & 4.1 & 604.8 & 0.0068 \\
\hline P2121 & C0004D-42R-3 & 335.42 & 1000 & 0.0232 & 5.1 & 589.8 & 0.0087 \\
\hline P2112 & C0004D-47R-2 & 357.11 & 1 & 0.0014 & 0.8 & 2381.9 & 0.0003 \\
\hline P2112 & C0004D-47R-2 & 357.11 & 3 & 0.0025 & 1.3 & 2344.1 & 0.0006 \\
\hline P2112 & C0004D-47R-2 & 357.11 & 10 & 0.0058 & 2.2 & 2306.8 & 0.0010 \\
\hline P2112 & C0004D-47R-2 & 357.11 & 30 & 0.0098 & 3.8 & 2269.0 & 0.0017 \\
\hline P2112 & C0004D-47R-2 & 357.11 & 100 & 0.0124 & 5.1 & 2231.8 & 0.0023 \\
\hline P2112 & C0004D-47R-2 & 357.11 & 300 & 0.0157 & 6.4 & 2194.0 & 0.0029 \\
\hline P2112 & C0004D-47R-2 & 357.11 & 1000 & 0.0187 & 8.9 & 2157.0 & 0.0041 \\
\hline
\end{tabular}


Table T3. Slide-hold-slide parameters, Site C0007.

\begin{tabular}{|c|c|c|c|c|c|c|c|}
\hline Experiment & Hole, core, section & $\begin{array}{l}\text { Depth } \\
\text { (mbsf) }\end{array}$ & $\begin{array}{l}\text { Hold } \\
\text { time (s) }\end{array}$ & $\Delta \mu$ & $\begin{array}{c}\Delta h \\
(\mu \mathrm{m})\end{array}$ & $\begin{array}{c}h \\
(\mu \mathrm{m})\end{array}$ & $\varepsilon$ \\
\hline & $316-$ & & & & & & \\
\hline P2654 & C0007C-11X-4 & 103.61 & 1 & 0.0019 & 0.6 & 2305.4 & 0.0003 \\
\hline P2654 & C0007C-11X-4 & 103.61 & 3 & 0.0039 & 1.8 & 2270.8 & 0.0008 \\
\hline P2654 & C0007C-11X-4 & 103.61 & 10 & 0.0063 & 3.2 & 2235.3 & 0.0014 \\
\hline P2654 & C0007C-11X-4 & 103.61 & 30 & 0.0095 & 4.4 & 2200.0 & 0.0020 \\
\hline P2654 & C0007C-11X-4 & 103.61 & 100 & 0.0124 & 6.6 & 2165.3 & 0.0030 \\
\hline P2654 & C0007C-11X-4 & 103.61 & 300 & 0.0156 & 8.6 & 2130.0 & 0.0040 \\
\hline P2654 & C0007C-11X-4 & 103.61 & 1000 & 0.0201 & 10.7 & 2094.4 & 0.0051 \\
\hline P2777 & C0007D-9R-2 & 249.37 & 1 & 0.0013 & 0.4 & 1177.8 & 0.0004 \\
\hline P2777 & C0007D-9R-2 & 249.37 & 3 & 0.0025 & 0.7 & 1158.5 & 0.0006 \\
\hline P2777 & C0007D-9R-2 & 249.37 & 10 & 0.0056 & 1.4 & 1139.8 & 0.0012 \\
\hline P2777 & C0007D-9R-2 & 249.37 & 30 & 0.0093 & 2.0 & 1121.3 & 0.0017 \\
\hline P2777 & C0007D-9R-2 & 249.37 & 100 & 0.0130 & 3.0 & 1102.7 & 0.0027 \\
\hline P2777 & C0007D-9R-2 & 249.37 & 300 & 0.0146 & 4.3 & 1083.8 & 0.0039 \\
\hline P2777 & C0007D-9R-2 & 249.37 & 1000 & 0.0186 & 4.9 & 1064.7 & 0.0046 \\
\hline P2640 & C0007D-16R-2 & 315.42 & 1 & 0.0003 & 0.9 & 1495.0 & 0.0006 \\
\hline P2640 & C0007D-16R-2 & 315.42 & 3 & 0.0009 & 1.1 & 1464.1 & 0.0008 \\
\hline P2640 & C0007D-16R-2 & 315.42 & 10 & 0.0021 & 1.7 & 1433.1 & 0.0012 \\
\hline P2640 & C0007D-16R-2 & 315.42 & 30 & 0.0061 & 3.4 & 1401.7 & 0.0024 \\
\hline P2640 & C0007D-16R-2 & 315.42 & 100 & 0.0094 & 4.7 & 1371.3 & 0.0035 \\
\hline P2640 & C0007D-16R-2 & 315.42 & 300 & 0.0110 & 6.4 & 1340.8 & 0.0048 \\
\hline P2640 & C0007D-16R-2 & 315.42 & 1000 & 0.0143 & 8.2 & 1310.6 & 0.0063 \\
\hline P2639 & C0007D-23R-2 & 381.14 & 1 & 0.0000 & 0.5 & 1103.5 & 0.0004 \\
\hline P2639 & C0007D-23R-2 & 381.14 & 3 & 0.0004 & 0.9 & 1078.6 & 0.0009 \\
\hline P2639 & C0007D-23R-2 & 381.14 & 10 & 0.0005 & 1.4 & 1054.0 & 0.0013 \\
\hline P2639 & C0007D-23R-2 & 381.14 & 30 & 0.0024 & 2.4 & 1029.6 & 0.0023 \\
\hline P2639 & C0007D-23R-2 & 381.14 & 100 & 0.0043 & 4.1 & 1005.1 & 0.0040 \\
\hline P2639 & C0007D-23R-2 & 381.14 & 300 & 0.0077 & 5.3 & 980.1 & 0.0054 \\
\hline P2639 & C0007D-23R-2 & 381.14 & 1000 & 0.0099 & 6.9 & 954.9 & 0.0072 \\
\hline P2655 & C0007D-24R-1 & 389.28 & 1 & 0.0002 & 0.3 & 703.5 & 0.0004 \\
\hline P2655 & C0007D-24R-1 & 389.28 & 3 & 0.0007 & 0.5 & 683.2 & 0.0007 \\
\hline P2655 & C0007D-24R-1 & 389.28 & 10 & 0.0014 & 1.1 & 662.6 & 0.0016 \\
\hline P2655 & C0007D-24R-1 & 389.28 & 30 & 0.0031 & 2.2 & 642.1 & 0.0034 \\
\hline P2655 & C0007D-24R-1 & 389.28 & 100 & 0.0051 & 2.9 & 620.6 & 0.0046 \\
\hline P2655 & C0007D-24R-1 & 389.28 & 300 & 0.0064 & 4.1 & 599.3 & 0.0068 \\
\hline P2655 & C0007D-24R-1 & 389.28 & 1000 & 0.0081 & 5.2 & 577.4 & 0.0090 \\
\hline P2656 & C0007D-24R-1 & 389.28 & 1 & 0.0000 & 0.1 & 596.5 & 0.0002 \\
\hline P2656 & C0007D-24R-1 & 389.28 & 3 & 0.0000 & 0.3 & 583.0 & 0.0006 \\
\hline P2656 & C0007D-24R-1 & 389.28 & 10 & 0.0006 & 0.5 & 569.5 & 0.0008 \\
\hline P2656 & C0007D-24R-1 & 389.28 & 30 & 0.0020 & 1.1 & 556.9 & 0.0019 \\
\hline P2656 & C0007D-24R-1 & 389.28 & 100 & 0.0050 & 2.3 & 544.2 & 0.0043 \\
\hline P2656 & C0007D-24R-1 & 389.28 & 300 & 0.0074 & 3.4 & 531.4 & 0.0064 \\
\hline P2656 & C0007D-24R-1 & 389.28 & 1000 & 0.0083 & 5.1 & 518.6 & 0.0099 \\
\hline P2644 & C0007D-27R-1 & 418.42 & 1 & 0.0006 & 0.4 & 1367.5 & 0.0003 \\
\hline P2644 & C0007D-27R-1 & 418.42 & 3 & 0.0013 & 0.9 & 1337.5 & 0.0007 \\
\hline P2644 & C0007D-27R-1 & 418.42 & 10 & 0.0027 & 1.6 & 1307.2 & 0.0012 \\
\hline P2644 & C0007D-27R-1 & 418.42 & 30 & 0.0044 & 2.9 & 1276.8 & 0.0023 \\
\hline P2644 & C0007D-27R-1 & 418.42 & 100 & 0.0066 & 5.0 & 1247.2 & 0.0040 \\
\hline P2644 & C0007D-27R-1 & 418.42 & 300 & 0.0086 & 5.7 & 1216.5 & 0.0047 \\
\hline P2644 & C0007D-27R-1 & 418.42 & 1000 & 0.0113 & 7.3 & 1186.4 & 0.0062 \\
\hline P2641 & C0007D-29R-1 & 437.19 & 1 & 0.0003 & 0.3 & 478.2 & 0.0006 \\
\hline P2641 & C0007D-29R-1 & 437.19 & 3 & -0.0002 & 0.7 & 462.4 & 0.0014 \\
\hline P2641 & C0007D-29R-1 & 437.19 & 10 & 0.0009 & 1.0 & 446.9 & 0.0022 \\
\hline P2641 & C0007D-29R-1 & 437.19 & 30 & 0.0024 & 2.0 & 430.9 & 0.0047 \\
\hline P2641 & C0007D-29R-1 & 437.19 & 100 & 0.0048 & 3.5 & 415.1 & 0.0085 \\
\hline P2641 & C0007D-29R-1 & 437.19 & 300 & 0.0077 & 4.8 & 399.4 & 0.0120 \\
\hline P2641 & C0007D-29R-1 & 437.19 & 1000 & 0.0091 & 6.1 & 383.0 & 0.0159 \\
\hline
\end{tabular}


Table T4. Parameters and best-fit curves for frictional healing and compaction.

\begin{tabular}{lcccccc}
\hline Experiment & Hole, core, section & $\begin{array}{c}\text { Depth } \\
\text { (mbsf) }\end{array}$ & $\begin{array}{c}\text { Healing rate } \\
\text { (per decade) }\end{array}$ & $\begin{array}{c}\text { Healing rate } \\
R^{2}\end{array}$ & $\begin{array}{c}\text { Compaction rate } \\
\text { (per decade) }\end{array}$ & $R^{2}$ \\
\hline & 316- & & & & & \\
P2118 & C0004C-15X-2 & 119.28 & 0.0050 & 0.998 & 0.0021 & 0.959 \\
P2627 & C0004D-22R-1 & 243.10 & 0.0066 & 0.991 & 0.0033 & 0.997 \\
P2102 & C0004D-27R-1 & 266.16 & 0.0075 & 0.971 & 0.0044 & 0.966 \\
P2069 & C0004D-29R-2 & 275.73 & 0.0062 & 0.998 & 0.0056 & 0.972 \\
P2067 & C0004D-30R-1 & 278.75 & 0.0049 & 0.986 & 0.0062 & 0.980 \\
P2068 & C0004D-34R-1 & 297.55 & 0.0054 & 0.987 & 0.0047 & 0.983 \\
P2121 & C0004D-42R-3 & 335.42 & 0.0079 & 0.998 & 0.0033 & 0.997 \\
P2112 & C0004D-47R-2 & 357.11 & 0.0063 & 0.994 & 0.0015 & 0.982 \\
P2654 & C0007C-11X-4 & 103.61 & 0.0068 & 0.993 & 0.0019 & 0.992 \\
& 316- & & & & & \\
P2777 & C0007D-9R-2 & 249.37 & 0.0063 & 0.987 & 0.0018 & 0.986 \\
P2640 & C0007D-16R-2 & 315.42 & 0.0059 & 0.982 & 0.0025 & 0.996 \\
P2639 & C0007D 23R-2 & 381.14 & 0.0048 & 0.987 & 0.0030 & 0.995 \\
P2655 & C0007D-24R-1 & 389.28 & 0.0033 & 0.997 & 0.0036 & 0.989 \\
P2656 & C0007D-24R-1 & 389.28 & 0.0042 & 0.973 & 0.0045 & 0.973 \\
P2644 & C0007D-27R-1 & 418.42 & 0.0043 & 0.995 & 0.0025 & 0.991 \\
P2641 & C0007D-29R-1 & 437.19 & 0.0044 & 0.985 & 0.0069 & 0.996 \\
\hline
\end{tabular}

Table T5. Normal stress step parameters.

\begin{tabular}{|c|c|c|c|c|c|c|}
\hline Experiment & Hole, core, section & $\begin{array}{l}\text { Depth } \\
\text { (mbsf) }\end{array}$ & $\Delta \sigma_{n}$ & $\begin{array}{c}\Delta h \\
(\mu \mathrm{m})\end{array}$ & $\begin{array}{c}h \\
(\mu \mathrm{m})\end{array}$ & $\varepsilon$ \\
\hline & $316-$ & & & & & \\
\hline P2118 & C0004C-15X-2 & 119.28 & -3.31 & -3.47 & 1164.8 & -0.0030 \\
\hline P2118 & C0004C-15X-2 & 119.28 & 4.4 & 4.7 & 1168.3 & 0.0040 \\
\hline P2118 & C0004C-15X-2 & 119.28 & -4.39 & -4.43 & 1163.6 & -0.0038 \\
\hline P2118 & C0004C-15X-2 & 119.28 & 4.3 & 4.4 & 1167.5 & 0.0038 \\
\hline P2069 & C0004D-29R-2 & 275.73 & 0.9 & 2.0 & 414.9 & 0.0048 \\
\hline P2069 & C0004D-29R-2 & 275.73 & 1.1 & 1.6 & 412.9 & 0.0038 \\
\hline P2069 & C0004D-29R-2 & 275.73 & -1 & -0.68 & 410.8 & -0.0017 \\
\hline P2069 & C0004D-29R-2 & 275.73 & -1.07 & -1.26 & 411.5 & -0.0031 \\
\hline P2069 & C0004D-29R-2 & 275.73 & -1 & -1.33 & 412.9 & -0.0032 \\
\hline P2069 & C0004D-29R-2 & 275.73 & -0.95 & -1.6 & 414.4 & -0.0039 \\
\hline P2069 & C0004D-29R-2 & 275.73 & 1.0 & 1.0 & 416.4 & 0.0025 \\
\hline P2069 & C0004D-29R-2 & 275.73 & 1.0 & 1.4 & 415.3 & 0.0033 \\
\hline P2067 & C0004D-30R-1 & 278.75 & 1.5 & 1.6 & 275.0 & 0.0057 \\
\hline P2067 & C0004D-30R-1 & 278.75 & -0.58 & -0.38 & 272.7 & -0.0014 \\
\hline P2067 & C0004D-30R-1 & 278.75 & -0.98 & -1.61 & 273.0 & -0.0059 \\
\hline P2067 & C0004D-30R-1 & 278.75 & -1.3 & -0.91 & 274.5 & -0.0033 \\
\hline P2067 & C0004D-30R-1 & 278.75 & -0.92 & -1.41 & 275.9 & -0.0051 \\
\hline P2068 & C0004D-34R-1 & 297.55 & 1.0 & 1.9 & 399.9 & 0.0047 \\
\hline P2068 & C0004D-34R-1 & 297.55 & 1.1 & 0.7 & 397.9 & 0.0019 \\
\hline P2068 & C0004D-34R-1 & 297.55 & -1.02 & -0.31 & 396.6 & -0.0008 \\
\hline P2068 & C0004D-34R-1 & 297.55 & -1.1 & -0.56 & 396.9 & -0.0014 \\
\hline P2068 & C0004D-34R-1 & 297.55 & -0.93 & -0.67 & 397.5 & -0.0017 \\
\hline P2068 & C0004D-34R-1 & 297.55 & -1.17 & -1.33 & 398.4 & -0.0033 \\
\hline P2068 & C0004D-34R-1 & 297.55 & 1.2 & 0.6 & 399.8 & 0.0016 \\
\hline P2068 & C0004D-34R-1 & 297.55 & 1.0 & 1.0 & 399.2 & 0.0025 \\
\hline P2121 & C0004D-42R-3 & 335.42 & 1.0 & 1.3 & 560.0 & 0.0023 \\
\hline P2121 & C0004D-42R-3 & 335.42 & -6.34 & -9.8 & 558.7 & -0.0175 \\
\hline P2121 & C0004D-42R-3 & 335.42 & 6.3 & 10.2 & 568.5 & 0.0179 \\
\hline P2121 & C0004D-42R-3 & 335.42 & -4.55 & -5.5 & 558.3 & -0.0099 \\
\hline P2121 & C0004D-42R-3 & 335.42 & 4.6 & 5.5 & 563.8 & 0.0098 \\
\hline P2112 & C0004D-47R-2 & 357.11 & -3.17 & -14.5 & 2094.5 & -0.0069 \\
\hline P2112 & C0004D-47R-2 & 357.11 & 4.2 & 20.3 & 2109.0 & 0.0096 \\
\hline P2112 & C0004D-47R-2 & 357.11 & -4.8 & -21.1 & 2088.7 & -0.0101 \\
\hline P2112 & C0004D-47R-2 & 357.11 & 4.2 & 21.5 & 2109.8 & 0.0102 \\
\hline
\end{tabular}


Table T6. Compressibility.

\begin{tabular}{lccccc}
\hline Experiment & Hole, core, section & $\begin{array}{c}\text { Depth } \\
(\mathrm{mbsf})\end{array}$ & $\begin{array}{c}\text { Compressibility } \\
\left(\mathrm{GPa}^{-1}\right)\end{array}$ & $\begin{array}{c}\text { Young's } \\
\text { modulus } \\
(\mathrm{GPa})\end{array}$ & $\begin{array}{c}\text { Linear fit } \\
R^{2}\end{array}$ \\
\hline & 316- & & & & \\
P2118 & C0004C-15X-2 & 119.28 & 0.89 & 1.12 & 0.999 \\
P2069 & C0004D-29R-2 & 275.73 & 3.26 & 0.31 & 0.932 \\
P2067 & C0004D-30R-1 & 278.75 & 3.85 & 0.26 & 0.885 \\
P2068 & C0004D-34R-1 & 297.55 & 2.07 & 0.48 & 0.786 \\
P2121 & C0004D-42R-3 & 335.42 & 2.58 & 0.39 & 0.986 \\
P2112 & C0004D-47R-2 & 357.11 & 2.26 & 0.44 & 0.999 \\
\hline
\end{tabular}

